\title{
Infekcije mokraćnog sustava povezane s uporabom urinarnih katetera - put do nula infekcija
}

\section{Catheter associated urinary tract infections - targeting zero infections}

\author{
Maja Abram ${ }^{1 *}$, Morana Magaš̌2, Ivana Škrobonja ${ }^{1}$, Nives Barać
}

${ }^{1}$ Klinički zavod za kliničku mikrobiologiju, Klinički bolnički centar Rijeka, Rijeka, Hrvatska

${ }^{2}$ Povjerenstvo za bolničke infekcije, Klinički bolnički centar Rijeka, Rijeka, Hrvatska

\author{
"Dopisni autor: \\ Prof. dr. sc. Maja Abram, dr. med. \\ Klinički zavod za kliničku mikrobiologiju, \\ Klinički bolnički centar Rijeka, \\ Krešimirova 42, 51000 Rijeka \\ E-mail: maja.abram@medri.uniri.hr
}

Sažetak. Transplantirani i ostali urološki pacijenti imaju češće potrebu za uvođenjem ureteralnog stenta, odnosno urinarnih katetera, te su izloženi povećanom riziku za stjecanje infekcija mokraćnog sustava (IMS). To je najčešća infektivna komplikacija u primatelja alogeničnog grafta, glavni izvor pijelonefritisa, bakterijemije i sepse. Također, IMS su najzastupljenije infekcije povezane sa zdravstvenom skrbi, a glavni rizični čimbenik za njihov nastanak je upravo prisustvo katetera. Vodeći uzročnici ovih infekcija su E. coli, E. faecalis, vrste iz roda Klebsiella, Proteus i Pseudomonas koje često karakterizira i višestruka antimikrobna rezistencija, što dodatno ugrožava klinički ishod. Radi praćenja IMS-a povezanih $s$ uporabom katetera svake se godine provodi jednodnevno presječno istraživanje kojim su obuhvaćeni svi pacijenti hospitalizirani taj dan. Rezultati pridonose sagledavanju problema, unaprjeđenju mjera prevencije, planiranju empirijske antimikrobne terapije, odnosno sigurnosti hospitaliziranih uroloških pacijenata.

Ključne riječi: infekcije mokraćnog sustava; kateter; patogeneza; presječno praćenje; prevencija

Abstract. Transplanted and other urological patients are more likely to need a ureteral stent, or urinary catheters, and are at increased risk of acquiring urinary tract infections (UTI). It is the most common infectious complication in the recipient of allogeneic graft, the main source of pyelonephritis, bacteremia and sepsis. Also, UTIs are the most common healthcare associated infections, and the main risk factor for their occurence is the use of urinary catheters. The leading agents of these infections are E. coli, E. faecalis, species of the genus Klebsiella, Proteus and Pseudomonas, often characterized by multiple antimicrobial resistance, further compromising clinical outcome. To monitor the catheter associated UTI, a one-day point-prevalence study is conducted every year, covering all patients hospitalized that day. The results contribute to the understanding of the problem, improvement of prevention measures, planning of empirical antimicrobial therapy, that is, the safety of hospitalized urological patients.

Key words: catheter; pathogenesis; point prevalence survey; prevention; urinary tract infections

http://hrcak.srce.hr/medicina 


\section{UVOD}

Infekcije povezane sa zdravstvenom skrbi predstavljaju značajan medicinski problem jer dovode do komplikacija primarnog oboljenja te povećanja pobola i smrtnosti. S obzirom na to da su takve infekcije najčešće uzrokovane višestruko-rezistentnim bakterijama, za liječenje je dostupan ograničen broj antimikrobnih lijekova, što je razlog produljene hospitalizacije, češćeg kliničkog neuspjeha terapijskih protokola i dodatnih troškova u zdravstvenom sustavu.

Infekcije mokraćnog sustava (IMS) jedna su od najčešćih bakterijskih infekcija u općoj populaciji koje godišnje pogađaju oko 150 milijuna ljudi širom svijeta. Također, IMS su najzastupljenije infekcije povezane sa zdravstvenom skrbi i čine više od $40 \%$ svih bolničkih infekcija, a glavni rizični čimbenik njihovog nastanka povezan je s korištenjem urinarnih katetera ${ }^{1}$. S obzirom na to da se, s vremenom, na svim umjetnim površinama stvara biofilm, glavna odrednica razvoja bakteriurije i s kateterom povezanih IMS-a je trajanje kateterizacije. U odraslih kateteriziranih pacijenata rizik od razvoja IMS-a povezanih s kateterom povećava se za $3-7 \%$ sa svakim danom kateterizacije, a jedan od trećine pacijenata $s$ bakteriurijom povezanom s uporabom urinarnih katetera razvit će sekundarnu bakterijemiju ${ }^{2,3}$. Urinarni kateteri izvor su za oko $20 \%$ epizoda stečene bakteremije u zdravstvenim ustanovama za akutnu skrb i preko $50 \%$ u drugim ustanovama za dugoročno zbrinjavanje i njegu.

\section{INFEKCIJA MOKRAĆNOG SUSTAVA} U TRANSPLANTIRANIH PACIJENATA

Transplantacija bubrega najbolji je izbor liječenja u pacijenata s uznapredovalom kroničnom bubrežnom bolešću koji je pridonio značajnom produljenju i kvaliteti njihova života. No, unatoč primjetnom napretku u kirurškom postupku i imunosupresivnoj terapiji nakon transplantacije bubrega, IMS ostaje važan problem u ovih pacijenata ${ }^{4}$. Radi se o jednoj od najčešćih infektivnih komplikacija koja se javlja u šest do $86 \%$ primatelja alogeničnog grafta i predstavlja glavni izvor pijelonefritisa, bakterijemije i sepse te je značajni uzrok slabe funkcije transplantata, pobola i smrtnosti ${ }^{4-6}$. Brojni su čimbenici rizika za stjecanje IMS-a u transplantiranih pacijenata: produljeno razdoblje hemodijalize i prethodnog IMS-a, starija dob, ženski spol, imunosupresija, trajanje postoperacijske kateterizacije i drugo. Razlike u stopama IMS-a mogu biti posljedica razine postoperacijske medicinske skrbi i imunosupresivne terapije u određenom centru, stupnju antimikrobne rezistencije na lokalnoj razini, higijenskim standardima ustanova i različitim dijagnostičkim kriterijima.

Dvostruka J proteza mokraćovoda (ureteralni stent) uobičajeno se umeće tijekom transplanta-

Infekcije mokraćnog sustava najzastupljenije su infekcije povezane sa zdravstvenom skrbi i čine više od $40 \%$ svih bolničkih infekcija, a glavni rizični čimbenik njihova nastanka povezan je s korištenjem urinarnih katetera.

cije bubrega kako bi se izbjegle rane komplikacije (nastanak urinarne fistule ili stenoze). No, terapijske prednosti ureteralnog stenta u transplantaciji bubrega još uvijek su kontroverzne. lako se široko koristi u zaštiti ureteroneocistostomije, predstavlja i predisponirajući faktor za razvoj IMS-a kao značajna prijetnja presatku i pacijentu, osobito tijekom imunosupresije u ranoj fazi nakon transplantacije ${ }^{7}$. lako Europsko društvo za urologiju, kao i nacionalne smjernice, preporučuju uklanjanje stenta unutar šest tjedana od transplantacije, optimalan vremenski okvir za ovo nije striktno definiran ${ }^{8,9}$. Stoga su posljednjih godina provedene brojne studije kako bi se definiralo vrijeme za uklanjanje ureteralnog stenta ${ }^{10-13}$. U 2019. godini objavljeni su rezultati opsežne metaanalize koji su pokazali da ranije uklanjanje stenta, prije trećeg postoperacijskog tjedna, ne dovodi do veće učestalosti nastanka urinarne fistule, a značajno smanjuje učestalost IMS-a u usporedbi s kasnijim uklanjanjem (> tri tjedna) ${ }^{13}$.

Pravovremeno prepoznavanje i dijagnoza IMS-a u transplantiranih pacijenata od iznimnog je značenja te se u poslijeoperacijskom periodu preporučuje provoditi redoviti mikrobiološki probir, posebno u prva tri mjeseca nakon transplantacije bubrega. Pokazalo se, međutim, da rutinska urinokultura, tj. analiza srednjeg mlaza urina, nije dovoljno precizna za otkrivanje kolonizacije ureteralnog stenta. lako još uvijek nema standardizi- 
ranih tehnika, u postupku istraživanja su nove metode, kao što su semikvantitativna tehnika rolanja katetera preko površine agara (roll plate), sonikacija (ultrazvučno razaranje biofilma) koja otkriva i endoluminalne mikroorganizme te unaprijeđena urinokultura (EQUC od engl. enhanced quantitative urine culture $)^{14,15}$. EQUC podrazumijeva inokulaciju većeg volumena urina na brojna mikrobiološka hranilišta koja se inkubiraju u različitim atmosferskim uvjetima.

PATOGENEZA INFEKCIJE MOKRAĆNOG

SUSTAVA POVEZANE S UPORABOM

URINARNOG KATETERA I URETERALNOG STENTA

Kod normalne funkcije mokraćnog sustava mokraća ispire mokraćnu cijev dok se mjehur prazni, sprječavajući kretanje bakterija iz periuretralne okoline u uretru, a potom u mjehur. Čak i ako bakterije uspiju ući u zdravi mokraćni mjehur, bit će izbačene tijekom mokrenja, a mucinski sloj na površini urotela, s poznatim antiadhezijskim kapacitetom, spriječit će prihvaćanje bakterija na zid mjehura ${ }^{16}$. Umetanjem stranog tijela povećava se rizik stjecanja IMS-a, jer kateteri predstavljaju mjesto inicijacije infekcije unošenjem oportunističkih mikroorganizama u mokraćovod. Urinarni kateteri pospješuju kolonizaciju uropatogena pružajući im dodatnu površinu za adherenciju, oštećujući uroepitelnu sluznicu i remeteći normalnu mehaničku obranu domaćina. Najmanje $66 \%$ IMS-a povezanih s uporabom urinarnih katetera rezultat su ekstraluminalne kontaminacije, unošenjem mikroorganizama prilikom umetanja katetera, odnosno ascendentnim putem iz periuretralne regije duž vanjske površine katetera. Bakterije mogu također ući u mjehur intraluminalo (34\%), gdje bakterije migriraju u mjehur kao rezultat manipulacije kateterskim sustavom. Mehanizmi ulaska se kombiniraju, zbog čega je teško spriječiti IMS u osoba koje imaju urinarni kateter dulje od dva tjedna ${ }^{16,17}$. Ureteralni stent također predstavlja idealnu površinu za mikrobnu kolonizaciju i stvaranje biofilma koji je vodeći uzrok začepljenja i disfunkcije stenta.

Nakon umetanja stranog tijela, proteini i druge organske molekule iz urina nakupljaju se na površini katetera mijenjajući njegove površinske karakteristike i olakšavajući adherenciju uropatogenih mikroorganizama, što je preduvjet za nastanak biofilma ${ }^{17,18}$. $U$ in vitro pokusima, inkubacijom stenta u urinu, Elwood i sur. otkrili su specifične citokeratine, glikozilirane proteine prisutne na površini uroepitelnih stanica, koji stvaraju adekvatne uvjete za daljnju adherenciju bakterija ${ }^{19}$. Uz to, čini se da proteini u krvi, kao što su hemoglobin i fibrinogen, također sudjeluju u pripremi površina stenta za daljnju mikrobnu kolonizaciju. Biofilm nije statički sloj bakterija i sluzi, već je živi organizam sastavljen od jedne ili više vrsta mikroorganizama i njihovog izlučenog polisaharidnog matriksa te komponenti deponiranih iz tjelesnih tekućina. Adherirane, sesilne bakterije se dijele stvarajući mikrokolonije, a zatim počinju izlučivati izvanstaničnu polisaharidnu sluz ili matriks koji je temelj arhitektonike biofilma. Konačno, mikroorganizmi i njihov matriks tvore trodimenzionalne strukture, stupove razdvojene prostorom ispunjenim tjelesnom tekućinom kojom primaju hranjive tvari, odstranjuju otpadne molekule i šalju kemijske signale jedni drugima u fenomenu zvanom „quorum sensing“ odnosno detekcija kvoru$\mathrm{ma}^{20-22}$.

Druge vrste bakterija i kvasaca mogu se pridružiti biofilmu, a interakcije među pojedinim vrstama odgovorne su za različiti, jedinstveni mikrookoliš u okviru određenog biofilma. Pod nepovoljnim uvjetima, poput iscrpljivanja hranjivih sastojaka ili prenapučenosti, sesilni mikroorganizmi mogu se odvojiti i postati slobodno plutajući ili planktonski ${ }^{23}$. Prisutnost planktonskih organizama u urinu može dovesti do simptomatske infekcije domaćina.

Nekoliko je ključnih karakteristika koje razlikuju bakterije iz biofilma od planktonskih oblika. Planktonske bakterije izložene su relativno ujednačenim uvjetima okoliša, dok su u biofilmu izložene gradijentu hranjivih tvari i otpadnih proizvoda, zbog čega su bakterijske subpopulacije u biofilmu fiziološki heterogene ${ }^{24}$. Druga važna razlika između ova dva načina života je da planktonske bakterije i one iz biofilma ne dijele identični proteomski i transkriptomski profil, što rezultira fenotipskim razlikama. Možda je najistaknutija fenotipska razlika činjenica da su bakterije u biofilmu značajno otpornije na antimikrobna sredstva od genetski 
identičnih planktonskih sojeva, zbog čega se infekcije uzrokovane biofilmom zadržavaju unatoč antibiotskoj terapiji ${ }^{25}$.

\section{UZROČNICI INFEKCIJE MOKRAĆNOG} SUSTAVA POVEZANE S UPORABOM URINARNOG KATETERA I URETERALNOG STENTA

lako mnogi mikroorganizmi uzrokuju IMS, u 80 $90 \%$ svih nekompliciranih i oko $65 \%$ kompliciranih IMS-a uzročnik je gram-negativna bakterija, Escherichia coli (E. coli). Uropatogeni sojevi E. coli (UPEC) razlikuju se od komenzalnih crijevnih ešerihija jer posjeduju brojne faktore virulencije: fimbrije, flagele, toksine, proteine vanjske membrane, siderofore itd., koji im omogućavaju perzistenciju u mokraćnom sustavu i izazivanje IMS. Ipak, u patogenezi IMS-a uzrokovanih UPEC sojevima najvažniju ulogu imaju fimbrije tipa 1 i Pfimbrije koje su odgovorne za prihvaćanje, adherenciju za epitelne stanice, invaziju tkiva, stvaranje biofilma i indukciju citokina ${ }^{18-26}$.

lako se smatraju sekundarnim uropatogenima, gram-pozitivni enterokoki su drugi vodeći uzrok kompliciranih (11\%) i treći vodeći uzrok nekompliciranih IMS-a $(5 \%)^{27}$. U patogenezi IMS-a značajni čimbenici virulencije su produkcija kazeinaze i želatinaze koje pridonose sposobnosti formiranja biofilma na mokraćnim kateterima ${ }^{28}$. E. faecalis je često jedan od članova polimikrobnih biofilmova na urinarnim kateterima te se istovremeno može naći $u$ zajednici $s$ drugim bakterijama, npr. Proteus mirabilis ( $P$. mirabilis) $\mathrm{i}$ Pseudomonas aeruginosa ( $P$. aeruginosa), pridonoseći težini kliničke slike i pogoršanja pijelonefritisa češće nego monomikrobna infekcija ${ }^{27,28}$.

\section{INFEKCIJE MOKRAĆNOG SUSTAVA NA \\ KLINICI ZA UROLOGIJU KLINIČKOG \\ BOLNIČKOG CENTRA RIJEKA U \\ PETOGODIŠNJEM RAZDOBLJU (2014. - 2018.)}

Kao što je prikazano na slici 1 , tijekom petogodišnjeg razdoblja (od 2014. do 2018. godine) od ukupnog broja uropatogena identificiranih iz uzoraka urina pacijenata hospitaliziranih na Klinici za urologiju KBC-a Rijeka, više od $40 \%$ izolata čine sojevi UPEC (24,6\%) i E. faecalis (21,8\%) (slika 1). Dodatnih $37 \%$ uzročnika IMS-a odnosi se na

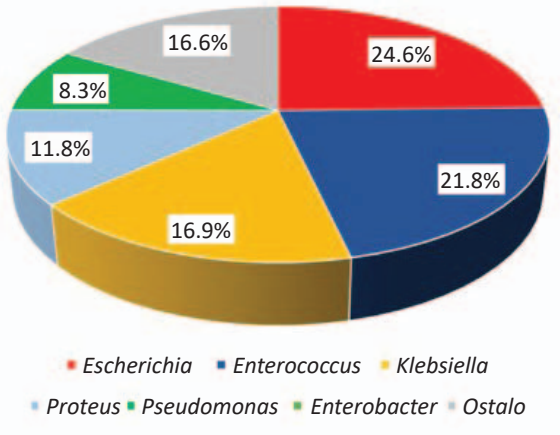

Slika 1. Raspodjela najčešćih uropatogena na Klinici za urologiju KBC-a Rijeka u razdoblju od 2014. do 2018. godine

bakterije iz roda Klebsiella (16,9\%), Proteus (11,8\%) i Pseudomonas (8,3\%), dok ostatak od $16,6 \%$ otpada na sve ostale uzročnike koji se pojavljuju rjeđe (ostale enterobakterije, Staphylococcus spp., Acinetobacter baumannii i dr.).

Prateći raspodjelu po pojedinim godinama, u pet vodećih uropatogena nalaze se već navedeni uzročnici (slika 2). No, može se uočiti da od 2016. godine opada broj E. coli (od $32 \%$ u 2014. do $14 \%$ u 2018. godini), dok raste broj enterokoka (od $19 \%$ u 2014. do $26 \%$ odnosno $25,5 \%$ u 2016. i 2017. godini). Unatoč porastu uropatogenih enterokoka, tijekom praćenog petogodišnjeg razdoblja niti u jednog izolata nije registrirana rezistencija prema glikopeptidima. No, visok je postotak gram-negativnih enterobakterija koje produciraju beta-laktamaze proširenog spektra (ESBL od engl. Extended Spectrum Beta-Lactama-

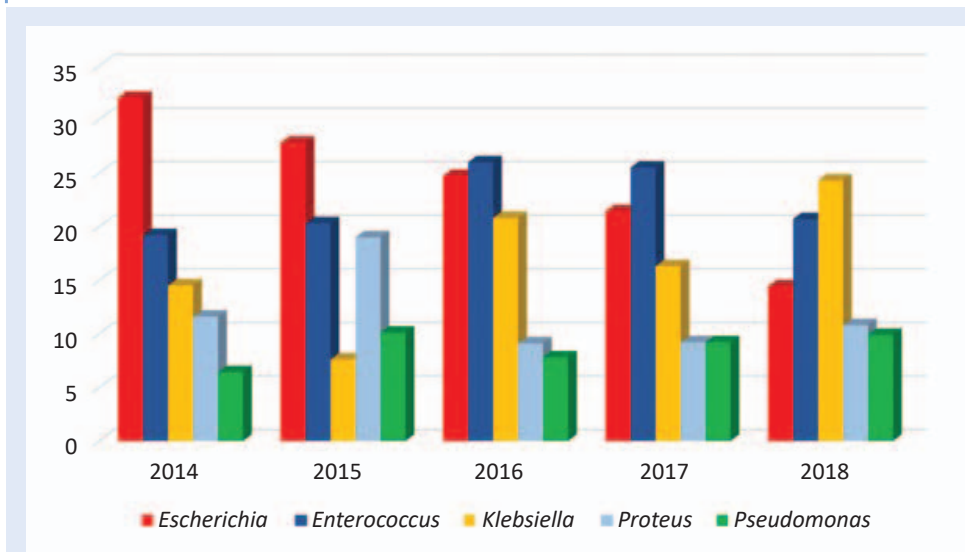

Slika 2. Godišnja raspodjela najčešćih uzročnika IMS-a na Klinici za urologiju KBC-a Rijeka 


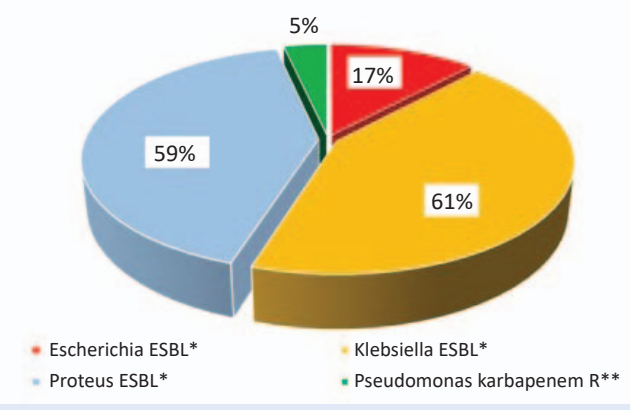

Slika 3. Udio višestrukorezistentnih bakterija među najčešćim uropatogenima u petogodišnjem radoblju (2014. - 2018.)

*ESBL = beta-laktamaze proširenog spektra; ${ }^{* *} \mathrm{R}=$ bakterija rezistentna na karbapeneme

se). U prosjeku, ESBL producirajućih E. coli bilo je oko $17 \%$, dok je više od polovine bakterija iz roda Proteus (uglavnom P. mirabilis) i roda Klebsiella (uglavnom K. pneumoniae) pokazivalo sposobnost produkcije ESBL-a (slika 3).

Prekomjerna uporaba urinarnih katetera pridonosi učestalosti bolničkih infekcija mokraćnog sustava, a trajanje kateterizacije je najvažniji faktor rizika za razvoj ovih infekcija. Rizik od stjecanja IMS-a povećava se za 3 - $7 \%$ svakim danom kateterizacije.

Pravovremeno prepoznavanje i dijagnoza IMS-a u transplantiranih pacijenata od iznimnog je značenja te se u poslijeoperacijskom periodu preporučuje provoditi redoviti mikrobiološki probir, posebno u prva tri mjeseca nakon transplantacije bubrega.

\section{PREVENCIJA INFEKCIJA MOKRAĆNOG \\ SUSTAVA POVEZANIH S URINARNIM KATETERIMA}

Prekomjerna uporaba urinarnih katetera pridonosi učestalosti bolničkih IMS-a, a trajanje kateterizacije je najvažniji faktor rizika za razvoj ovih infekcija. Rizik od stjecanja IMS-a povećava se za 3- $7 \%$ sa svakim danom kateterizacije. Kalkulacije koliko se IMS-a povezanih s kateterom može spriječiti uvelike variraju i kreću se od $17 \%$ do 69 \%. Ipak, svi se slažu da se učestalost IMS-a povezanih s urinarnim kateterima može smanjiti pod uvjetom da se primjenjuju sljedeća načela: primjerena uporaba katetera prema jasnim indikacijama, aseptično umetanje, uporaba zatvorenih drenažnih sustava, pravilno održavanje i rano uklanjanje trajnih mokraćnih katetera te higijena ruku² ${ }^{29}$.

Kontrola odbacivanja, sprječavanje i liječenje infekcije glavni su problemi u uspješnoj transplantaciji bubrega. Parenteralna antimikrobna profilaksa mokraćne infekcije povezane s kateterizacijom u razdoblju nakon transplantacije bubrega primjenjuje se u većini transplantacijskih centara. No, svjetski je trend smanjenje uporabe sistemske profilakse, jer nije dokazana razlika u učestalosti IMS-a u onih pacijenata koji su primali profilaksu u odnosu na one bez profilaktične primjene antibiotika.

Praćenje IMS-a povezanih s korištenjem trajnog pomagala jedna je od mjera uspješnog ishoda liječenja za pacijente u kojih je indicirano postavljanje urinarnog katetera. Praćenje podrazumijeva sustavno, kontinuirano prikupljanje, obradu i analizu podataka uz pravovremeno širenje informacije onima kojima su te informacije potrebne kako bi poduzeli odgovarajuće akcije. Radnje se obično odnose na poboljšanja u prevenciji ili kontroli IMS-a povezanih s urinarnim kateterom. U sklopu nacionalnog i europskog programa u KBC-u Rijeka svake se godine u listopadu provodi presječno praćenje (PPS od engl. Point Prevalence Survey) kojim su obuhvaćeni svi pacijenti hospitalizirani na dan provođenja studije ${ }^{30}$. Također, bilježi se broj pacijenata na pojedinoj klinici/odjelu, broj pacijenata s urinarnim kateterom, broj IMS-a povezanih s uporabom katetera, klasifikacija urinarne infekcije (mikrobiološki potvrđeni ili nepotvrđeni simptomatski IMS) te razlog uvođenja katetera. Iz studije su isključeni pacijenti koji na dan praćenja imaju operativni zahvat, pacijenti jednodnevne kirurgije, hitne službe, kao i ambulantni pacijen$\mathrm{ti}^{30-31}$.

U tablici 1 prikazani su rezultati koji se odnose na Kliniku za urologiju KBC-a Rijeka. Učestalost IMS-a povezanih s urinarnim kateterom izražena je kao broj infekcija na 1000 kateter dana koja je izračunata prema sljedećoj formuli:

$$
\text { stopa IMS }=\frac{\begin{array}{c}
\text { broj IMS povezanih } \\
\text { s urinarnim kateterom }
\end{array}}{\text { broj dana katetera }} \times 1000
$$


Tablica 1. Rezultati presječne studije za Kliniku za urologiju u razdoblju od 2014. do 2018. godine

\begin{tabular}{|c|c|c|c|c|c|c|}
\hline & \multicolumn{5}{|c|}{ Godina } & \multirow{2}{*}{ Ukupno } \\
\hline & 2014. & 2015. & 2016. & 2017. & 2018. & \\
\hline Broj pacijenata & 25 & 29 & 29 & 24 & 30 & 137 \\
\hline Broj pacijenata s urinarnim kateterom & $\begin{array}{c}11 \\
(44 \%)\end{array}$ & $\begin{array}{c}8 \\
(27,6 \%)\end{array}$ & $\begin{array}{c}12 \\
(41,4 \%)\end{array}$ & $\begin{array}{c}16 \\
(66,7 \%)\end{array}$ & $\begin{array}{c}18 \\
(60 \%)\end{array}$ & $\begin{array}{c}65 \\
(47,4 \%)\end{array}$ \\
\hline Broj kateter dana & 65 & 30 & 47 & 81 & 67 & 290 \\
\hline Broj pacijenata s kateterom povezanom IMS & 1 & 1 & 1 & 0 & 0 & 3 \\
\hline Stopa IMS/1000 kateter dana & 15 & 33 & 21 & 0 & 0 & 10 \\
\hline
\end{tabular}

Tablica 2. Indikacije za uporabu urinarnih katetera na Klinici za urologiju tijekom presječnog praćenja u razdoblju od 2014 . do 2018. godine

\begin{tabular}{|c|c|c|c|c|c|c|}
\hline \multirow{2}{*}{ Indikacije za uporabu katetera } & \multicolumn{5}{|c|}{ Godina } & \multirow{2}{*}{ Ukupno } \\
\hline & 2014. & 2015. & 2016. & 2017. & 2018. & \\
\hline Urološka operacija & 6 & 2 & 12 & 15 & 16 & 51 \\
\hline Retencija urina & 5 & 5 & 0 & 0 & 1 & 11 \\
\hline Masivna hematurija s ugrušcima u urinu & 0 & 0 & 0 & 1 & 1 & 2 \\
\hline $\begin{array}{l}\text { Inkontinencija urina u pacijenata s } \\
\text { dekubitusom }\end{array}$ & 0 & 1 & 0 & 0 & 0 & 1 \\
\hline Ukupno & 11 & 8 & 12 & 16 & 18 & 65 \\
\hline
\end{tabular}

Klinika za urologiju raspolaže s 33 bolesnička kreveta, a na dan provođenja PPS-a bilo je zaprimljeno od 24 do 30 pacijenata, čime je tijekom petogodišnjeg razdoblja obuhvaćeno ukupno 137 pacijenata. Na dan praćenja, broj pacijenata s urinarnim kateterom kretao se od 8 do 18 , što znači da je nešto manje od polovine ukupnog broja hospitaliziranih pacijenata na dan PPS-a imalo postavljen urinarni kateter. Broj dana katetera kretao se od 30 u 2015. do 81 u 2017. godini. Ukupni broj dana katetera tijekom petogodišnjeg jednodnevnog provođenja PPS-a iznosi 290 dana. Po jedan simptomatski i mikrobiološki potvrđeni IMS povezan s uporabom urinarnog katetera i stečen tijekom hospitalizacije zabilježen je u 2014., 2015. i 2016. godini, a izračunata stopa IMS-a u prosjeku iznosi 10 epizoda na 1000 kateter dana. Urološki pacijenti imaju specifične probleme najčešće izravno vezane uz poremećaj urinarnog sustava, zbog čega postoji potreba za češćim korištenjem urinarnih katetera, što rezultira povećanim rizikom za razvoj IMS-a u uroloških pacijenata ${ }^{32}$. S obzirom na navedeno, nije neobično da se tijekom petogodišnjeg razdoblja na Klinici za urologiju ne uočava smanjenje broja dana katetera, ali je pozitivno što se smanjuje broj IMS-a, što znači da se uspješno provode mjere prevencije.
Smatra se da se do jedne polovine urinarnih katetera koristi zbog neprimjerene indikacije. Zato smo tijekom PPS-a pratili i razloge za postavljanja urinarnih katetera kako bismo procijenili jesu li inidikacije za uporabu trajnih katetera u hospitaliziranih pacijenata bile odgovarajuće ${ }^{30-32}$. Najčešće zastupljena indikacija bila je uporaba urinarnih katetera nakon uroloških operacija, kada se, ovisno o vrsti operacijskog zahvata, kateterom omogućavalo odgovarajuće zacjeljivanje ili kontrolirano otjecanje urina te evakuacija krvnih ugrušaka (tablica 2). Sljedeće indikacije bile su retencija urina zbog opstrukcije izlaza iz mjehura i masivna hematurija s ugrušcima u urinu. Samo u jednom slučaju razlog postavljanja urinarnog katetera bila je inkontinencija, no radilo se o njezi sakralne rane $u$ inkontinentnog pacijenta, što se smatra opravdanom indikacijom.

\section{PUT PREMA CILJU: NULA INFEKCIJA \\ MOKRAĆNOG SUSTAVA POVEZANIH S URINARNIM KATETERIMA}

Infekcije povezane sa zdravstvenom skrbi ozbiljno ugrožavaju sigurnost pacijenata u smislu komplikacija primarnog oboljenja te povećanja morbiditeta, kao i smrtnosti. Među njima su najčešće infekcije mokraćnog sustava, a temeljni faktor ri- 
zika za njihov nastanak predstavlja uporaba urinarnih katetera. Dodatnu zabrinutost izaziva činjenica da su uropatogeni koji izazivaju ove infekcije obično višestrukorezistentni, zbog čega su mogućnosti liječenja ograničene. Smanjenje rizika i, prema tome, raširenosti infekcija povezanih sa zdravstvenim zaštitom, ključni su prioritet $u$ svim zdravstvenim sustavima, a u tu je svrhu praćenje i nadzor od izuzetne koristi.

Praćenje učestalosti i ishoda IMS-a povezanih s urinarnim kateterima, kao i poznavanje stope antimikrobne rezistencije, važni su parametri kvalitete koji se redovito prikupljaju u KBC-u Rijeka u okviru lokalnih, nacionalnih i međunarodnih programa. Dobiveni rezultati pružaju uvid u stanje na razini cijele bolnice, ali i na razini pojedinih klinika/odjela, što je značajno zbog osobitosti pacijenata koje zbrinjavaju. Tako urološki pacijenti imaju češće potrebu za uvođenjem urinarnih katetera te su izloženi povećanom riziku za stjecanje bolničkih I MS-a.

Rezultati ove i sličnih studija pridonose sagledavanju eventualnih problema te pripremi preporuka i postupnika za adekvatne mjere prevencije i empirijske antimikrobne terapije u hospitaliziranih uroloških pacijenata. Postupci prevencije usmjereni su na edukaciju zdravstvenog osoblja, smanjenje nepotrebne uporabe urinarnih katetera, njihovo pravovremeno uklanjanje te optimizaciju antibiotske terapije u uroloških pacijenata sa stečenim IMS-om. Naposljetku, dobiveni podatci poboljšat će sigurnost pacijenata kroz procjenu, primjenu i promjenu kliničke prakse.

Izjava o sukobu interesa: Autori izjavljuju da ne postoji sukob interesa.

\section{LITERATURA}

1. Foxman B. The epidemiology of urinary tract infection. Nat Rev Urol 2010;7:653-60.

2. Saint S. Clinical and economic consequences of nosocomial catheter-related bacteriuria. Am J Infect Control 2000;28:68-75.

3. Melzer $\mathrm{M}$, Welch $\mathrm{C}$. Does the presence of a urinary catheter predict severe sepsis in a bacteraemic cohort? J Hosp Infect 2017;95:376-82.

4. Ak O, Yildirim M, Kucuk HF, Gencer S, Demir T. Infections in renal transplant patients: Risk factors and infectious agents. Transplant Proc 2013;45:944-8.

5. Ariza-Heredia EJ, Beam EN, Lesnick TG, Cosio FG, Kremers WK, Razonable RR. Impact of urinary tract infection on allograft function after kidney transplantation. Clin Transplant 2014;28:683-90.
6. Karuthu S, Blumberg EA. Common infections in kidney transplant recipients. Clin J Am Soc Nephrol 2012;7: 2058-70.

7. Bonkat G, Rieken M, Müller G, Roosen A, Siegel FP, Frei R et al. Microbial colonization and ureteral stent-associated storage lower urinary tract symptoms: the forgotten piece of the puzzle? World J Urol 2013;31:541-6.

8. Rodríguez Faba O, Boissier R, Budde K, Figueiredo A, Taylor CF, Hevia V et al. European Association of Urology Guidelines on Renal Transplantation: Update 2018. Eur Urol Focus 2018;4:208-15.

9. Nacionalna radna grupa za presađivanje bubrega. Nacionalne smjernice za obradu i procjenu primatelja i darivatelja bubrega. 2. izd. [Internet]. Ministarstvo zdravlja Republike Hrvatske. 2016. [cited 2019 Dec 18]. Available from: https://zdravlje.gov.hr/UserDocsImages/ dokumenti/Tekstovi\%20razni/Smjernice2016_prilozi. pdf.

10. Liu S, Luo G, Sun B, Lu J, Zu Q, Yang S et al. Early removal of double-J stents decreases urinary tract infections in living donor renal transplantation: A prospective, randomized clinical trial. Transplant Proc 2017;49:297-302.

11. Kumar V, Punatar CB, Jadhav KK, Kothari J, Joshi VS, Sagade $\mathrm{SN}$ et al. Routine double-J stenting for live related donor kidney transplant recipients: It doesn't serve the purpose, but does it serve a better purpose? Investig Clin Urol 2018;59:410-5.

12. Thompson ER, Hosgood SA, Nicholson ML, Wilson $\mathrm{CH}$. Early versus late ureteric stent removal after kidney transplantation. Cochrane Database Syst Rev [Internet]. 2018;1: CD011455 [cited 2019 Dec 18]. Available from: https://www.ncbi.nlm.nih.gov/pmc/articles/ PMC6491073/pdf/CD011455.pdf.

13. Visser IJ, van der Staaij JPT, Muthusamy A, Willicombe M, Lafranca JA, Dor FJMF. Timing of Ureteric Stent Removal and Occurrence of Urological Complications after Kidney Transplantation: A Systematic Review and MetaAnalysis. J Clin Med [Internet]. 2019;8:689 [cited 2019 Dec 18]. Available from: https://www.ncbi.nlm.nih.gov/ pmc/articles/PMC6572676/pdf/jcm-08-00689.pdf.

14. Bonkat G, Braissant O, Rieken M, Müller G, Frei R, van der Merwe $A$ et al. Comparison of the roll-plate and sonication techniques in the diagnosis of microbial ureteral stent colonisation: results of the first prospective randomised study. World J Urol 2013;31:579-84.

15. Price TK, Dune T, Hilt EE, Thomas-White KJ, Kliethermes $S$, Brincat $C$ et al. The Clinical Urine Culture: Enhanced Techniques Improve Detection of Clinically Relevant Microorganisms. J Clin Microbiol 2016;54:1216-22.

16. Parsons $\mathrm{CL}$, Mulholland SG. Bladder surface mucin. Its antibacterial effect against various bacterial species. Am J Pathol 1978;93:423-32.

17. Pascual A. Pathogenesis of catheter-related infections: lessons for new designs. Clin Microbiol Infect 2002;8: 256-64.

18. Spaulding CN, Hultgren SJ. Adhesive Pili in UTI Pathogenesis and Drug Development. Pathogens [Internet]. 2016;15:5(1). [cited 2019 Dec 15]. Available from: https://www.mdpi.com/2076-0817/5/1/30/htm.

19. Elwood CN, Lo J, Chou E, Crowe A, Arsovska O, Adomat $\mathrm{H}$ et al. Understanding urinary conditioning film components on ureteral stents: profiling protein components and evaluating their role in bacterial colonization. Biofouling 2013;29:1115-22. 
20. Davies DG, Parsek MR, Pearson JP, Iglewski BH, Costerton JW, Greenberg EP. The involvement of cell-to-cell signals in the development of a bacterial biofilm. Science 1998;280:295-8.

21. Donlan RM. Biofilm formation: a clinically relevant microbiological process. Clin Infect Dis 2001;33:1387-92.

22. Watnick P1, Kolter R. Biofilm, city of microbes. J Bacteriol 2000;182:2675-9.

23. Sabir N, Ikram A, Zaman G, Satti L, Gardezi A, Ahmed A et al. Bacterial biofilm-based catheter-associated urinary tract infections: Causative pathogens and antibiotic resistance. Am J Infect Control 2017;45:1101-5.

24. Stewart PS, Franklin MJ. Physiological heterogeneity in biofilms. Nat Rev Microbiol 2008;6:199-210.

25. Hall CW, Mah TF. Molecular mechanisms of biofilmbased antibiotic resistance and tolerance in pathogenic bacteria. FEMS Microbiol Rev 2017;41:276-301.

26. Shah C, Baral R, Bartaula B, Shrestha LB. Virulence factors of uropathogenic Escherichia coli (UPEC) and correlation with antimicrobial resistance. BMC Microbiol [Internet]. 2019;19:204 [cited 2019 Dec 15]. Available from: https://bmcmicrobiol.biomedcentral.com/articles/ 10.1186/s12866-019-1587-3.
27. Nandini MS, Madhusudan K. Bacteriological Profile of Catheter Associated Urinary Tract Infection and its Antimicrobial Susceptibility Pattern in a Tertiary Care Hospital. J Pharm Sci Res 2016;8:204-7.

28. Repac Antić D, Gobin I, Begić G, Štifter S, Abram M. Fenotipska karakterizacija $\mathrm{i}$ antimikrobni profil uropatogenih enterokoka. Medicina Fluminensis 2018;54:304-11.

29. Francolini I, Donelli G. Prevention and control of biofilmbased medical-device-related infections. FEMS Immunol Med Microbiol 2010;59:227-38.

30. ECDC. Point prevalence survey of healthcare associated infections and antimicrobial use in European acute care hospitals-protocol version 5.3. European Centre for Disease Prevention and Control Stockholm: ECDC, 2016.

31. Andrade VL, Fernandes FA. Prevention of catheter-associated urinary tract infection: implementation strategies of international guidelines. Rev Lat Am Enfermagem [Internet]. 2016;24:e2678. [cited 2019 Dec 15]. Available from: https://www.ncbi.nlm.nih.gov/pmc/articles/ PMC4809180/.

32. Markić D, Strčić N, Markić I. Kateterizacija mokraćnoga mjehura - suvremeni pristup. Medicina Fluminensis 2014;2:158-68. 